\section{- OPEN ACCESS}

\title{
87-year-old woman with improved pulmonary function following accidental long-term inhalation therapy with dabigatran
}

\author{
Volker Pönitz, Karl Jakob Evensen
}

Department of Cardiology, Stavanger University Hospital, Stavanger, Norway

Correspondence to Dr Volker Pönitz, povo@sus.no

Accepted 28 August 2018

\section{SUMMARY}

Accidental long-term dabigatran etexilate inhalation was associated with subtherapeutic dabigatran serum concentrations in an elderly female patient with restrictive lung disease. A significant improvement in her pulmonary function was noted without other therapy directed towards her bronchopulmonary disease.

\section{BACKGROUND}

To our knowledge, this is the first report of inhalation treatment with dabigatran etexilate in humans, demonstrated by a measurable uptake through the pulmonary tract.

Additionally, we observed a marked improvement in pulmonary function compared with previous spirometry measurements, suggesting a potential beneficial effect of dabigatran on pulmonary function.

\section{CASE PRESENTATION}

A 87-year-old patient with a medical history of chronic obstructive pulmonary disease (COPD) was admitted with atrial fibrillation of unknown duration in February 2014. Following admission, she was anticoagulated with dabigatran (dabigatran etexilate) $110 \mathrm{mg}$ two times a day and treated with metoprolol $50 \mathrm{mg}$. Prior to hospitalisation, the patient was treated with Spiriva (Tiotropium) $18 \mu \mathrm{g}$ four times a day administrated by Handihaler and Onbrez (indacaterol maleate) four times a day administrated by a Onbreez Breezhaler. Both medications were prescribed by her family physician due to suspected COPD. Transthoracic echocardiography on admission revealed preserved systolic function with signs of diastolic dysfunction. Due to radiographic signs of pulmonary congestion, she was also treated with an ACE inhibitor and a loop diuretic. The patient was discharged after 2 days of hospitalisation.

Five months later, she was readmitted with recurrent symptoms of dyspnoea. Clinical and radiographical findings were consistent with pulmonary congestion. At admission, ECG showed atrial fibrillation with a heart rate of 150 beats per minute. The metoprolol dose was increased to $100 \mathrm{mg}$ two times a day and digoxin $(0.125 \mathrm{mg}$ once in a day) was added to her medication for sufficient rate control. She was subsequently discharged with a planned outpatient cardioversion after at least 3 weeks of continued anticoagulation.
In September 2014, she was readmitted with a history of a swollen and painful right leg over a long period of time. Deep vein thrombosis was deemed unlikely due to a low concentration of plasma D-dimer $(0.33 \mathrm{mg} / \mathrm{L}$; ULN $0.50 \mathrm{mg} / \mathrm{L})$ and ongoing anticoagulation treatment. The Wells score was only modestly raised and a phlebography was not performed.

She showed no signs of airway obstruction or congestion and an X-ray of the lungs revealed normal findings. Due to urinary infection symptoms and positive urine dipsticks, she was treated with pivmecillinam and was discharged in good clinical condition the day after admission.

While taking her medication during the hospital stay, she remarked that she used the blue/white pill' as a regular inhalation medication. She was asked to demonstrate how she took her medication, whereupon she put one capsule of dabigatran in the Handihaler, pressed the release button thereby releasing the granules and inhaled correctly. Interestingly, she reported that she had been taking dabigatran in that manner two times a day since February 2014 (approximately 6 months). She also confirmed that she had not been taking the original prescribed inhalation medicine for her COPD (Spiriva, Onbrez) during that period.

\section{INVESTIGATIONS}

Blood samples showed a measurable, but subtherapeutic, serum concentration of dabigatran ( $45 \mathrm{nmol} / \mathrm{L}$ taken 12 hours after the last inhalative administration and without any oral administration: therapeutic range $100-400 \mathrm{nmol} / \mathrm{L}$ 12 hours following administration). Activated partial thromboplastin time was slightly increased to $42 \mathrm{~s}$ (normal value $25-33 \mathrm{~s}$ ) and the international normalised ratio was slightly increased at 1.3 (normal value 0.9-1.2). Serum troponin I concentrations were slightly increased (as during the previous admissions) to $44 \mathrm{ng} / \mathrm{L}$ (upper limit normal (ULN) $15 \mathrm{ng} / \mathrm{L}$ ) without the typical rise and fall pattern seen in infarction, and plasma brain natriuretic peptide (BNP) was $253 \mathrm{pg} / \mathrm{mL}$ (ULN $100 \mathrm{ng} / \mathrm{mL}$ ) compared with $762 \mathrm{pg} / \mathrm{mL}$ during the previous admission.

There was a discrete increase in alanine aminotransferase (62 U/L, ULN $45 \mathrm{U} / \mathrm{L})$ and $\gamma$-glutamyltranspeptidase (97U/L, ULN $75 \mathrm{U} / \mathrm{L})$, while alkaline phosphatase was within the normal range. 


\begin{tabular}{|c|c|c|}
\hline & 2010 & 2014 \\
\hline FVC (L (\%PRED)) & $1.25(65.3)$ & $2.36(137.6)$ \\
\hline FEV1 (L (\%PRED)) & $1.04(68.0)$ & 1.57 (116.6) \\
\hline FEV1\%/FVC (\%(\% PRED)) & $83(113)$ & $66.6(91.8)$ \\
\hline
\end{tabular}

FEV1, forced expiratory volume in $1 \mathrm{~s}$; FVC, forced vital capacity; \%PRED, percentage of predicted value.

A previously performed spirometric examination of the patient in August 2010 showed a restrictive pattern with reduction of percentage of both forced vital capacity and forced expiratory volume in $1 \mathrm{~s}$ (FEV1) to $65.3 \%$ and $68.0 \%$ of normal values, respectively (table 1 ). At that time point, no pulmonary infection was present; X-ray of the lungs showed no abnormalities and the patient assured the medical staff that she had never smoked.

Interestingly, a control spirometry performed during the present hospital admission showed a marked improvement in pulmonary function compared with 2010, with increasing values of both FVC and FEV1 to high normal values (table 1), without administration of bronchodilator therapy.

\section{OUTCOME AND FOLLOW-UP}

The patient was instructed how to take her inhalation and oral medication correctly before she was discharged from the hospital.

\section{DISCUSSION}

In this patient, we demonstrated subtherapeutic serum concentrations of dabigatran consistent with pulmonary uptake of the drug following long-term accidental inhalation. Furthermore, a repeat spirometry in this patient with previous reduced spirometry readings with a restrictive pattern showed a marked improvement. This improvement occurred in the absence of any specific bronchodilatory therapy during the last 6 months.

Dabigatran etexilate is a small molecule acting as a prodrug without pharmacological activity. It is completely converted to dabigatran by esterase catalysed by hydrolysis in the plasma and the liver. To our knowledge, the pharmacokinetics for dabigatran etexilate through the respiratory tract and pulmonary tissue has not yet been clarified.

However, there is some evidence for the presence of serum esterases, as a potential activator for dabigatran etexilate in the lungs, including detection of release by human alveolar macrophages ${ }^{1}$ and detection of esterase activity in animal models in the lamellar bodies of the giant alveolar cells and in squamous, epithelial and endothelial cells. ${ }^{2}$

The therapeutic concept of anticoagulant treatment for interstitial lung disease has been investigated in several studies during the last years. However, most data originate from retrospective studies. Findings are conflicting, and benefits may be masked by increases in mortality and bleeding complications in warfarin-treated patients. One randomised placebo-controlled trial investigating warfarin versus placebo treatment in patients with progressive idiopathic pulmonary fibrosis had to be terminated prematurely due to an increased bleeding rate in patients treated with warfarin. ${ }^{3}$

Generation of thrombin on activation of the coagulation cascade has been documented in various forms of lung injury. ${ }^{4} 5$ Thrombin increases lung fibroblast proliferation, promotes differentiation of lung fibroblasts to myofibroblasts and is important in the cascade of fibrogenic cytokines.

Dabigatran reversibly binds to thrombin and prevents cleavage and activation of the protease-activated receptor 1 (PAR-1). Activated PAR-1 is responsible for most profibrotic events induced by thrombin. ${ }^{6}$

In animal models utilising mice with bleomycin induced pulmonary fibrosis, peroral treatment with dabigatran was associated with a marked anti-inflammatory and antifibrotic effect and it has been postulated that thrombin inhibition might represent a novel therapeutic option in the treatment of interstitial lung disease. ${ }^{7}$

To our knowledge, this is the first report of inhalation treatment with dabigatran etexilate in humans, demonstrated by a measurable uptake through the pulmonary tract. A marked improvement in pulmonary function was noticed compared with measurements taken 4 years previously.

Improvement of pulmonary congestion could be another possible explanation for her improved spirometry readings. However, this seems unlikely as in contrast to her admissions in February and July 2014 and consistent in the findings from 2010 and September 2014, no clinical signs of congestion were evident. Moreover, an X-ray of the lungs showed normal findings in 2010. Unfortunately, BNP measurements were not taken routinely yet at our centre in 2010 .

Finally, our observation may suggest a beneficial effect of dabigatran on pulmonary function. If such an effect is present, it is still a question whether it is mainly related to a systemic or topic mode of action of the drug. Presently, we do not know if oral administration of dabigatran has beneficial effects on pulmonary function in humans, and the drug is not approved for inhalation and could be hazardous.

Together with the previous findings from animal studies, our findings may encourage further research regarding a potential antifibrotic effect of topically administered novel oral anticoagulants in interstitial lung disease.

\section{Learning points}

- Erroneous inhalation of dabigatran etexilate was associated with measurable dabigatran serum concentrations.

- An improvement in pulmonary function was noticed following long-term inhalative treatment with dabigatran.

- The correct administration technique of medications should be ensured, in particular in elderly patients.

Contributors VP and KJE have contributed to the data collection, data interpretation and manuscript writing of the current case report.

Funding The authors have not declared a specific grant for this research from any funding agency in the public, commercial or not-for-profit sectors.

Competing interests VP has received honorary fees from Boehringer ingelheim, Pfitzer, BMS.

\section{Patient consent Obtained.}

Provenance and peer review Not commissioned; externally peer reviewed.

Open access This is an open access article distributed in accordance with the Creative Commons Attribution Non Commercial (CC BY-NC 4.0) license, which permits others to distribute, remix, adapt, build upon this work non-commercially, and license their derivative works on different terms, provided the original work is properly cited and the use is non-commercial. See: http://creativecommons.org/ licenses/by-nc/4.0/

\section{REFERENCES}

1 Jaubert F, Monnet JP, Danel C, et al. The location of non-specific esterase in human lung macrophages. An ultrastructural study. Histochemistry 1978;59:141-7. 
2 Vatter AE, Reiss OK, Newman JK, et al. Enzymes of the lung. I. Detection of esterase with a new cytochemical method. J Cell Biol 1968;38:80-98.

3 Noth I, Anstrom KJ, Calvert SB, et al. A placebo-controlled randomized trial of warfarin in idiopathic pulmonary fibrosis. Am J Respir Crit Care Med 2012;186:88-95.

4 Chambers RC. Procoagulant signalling mechanisms in lung inflammation and fibrosis: novel opportunities for pharmacological intervention? Br J Pharmacol 2008;153(Suppl 1):S367-S378.
5 Howell DC, Laurent GJ, Chambers RC. Role of thrombin and its major cellular receptor, protease-activated receptor-1, in pulmonary fibrosis. Biochem Soc Trans 2002;30:211-6.

6 Bogatkevich GS, Ludwicka-Bradley A, Silver RM. Dabigatran, a direct thrombin inhibitor, demonstrates antifibrotic effects on lung fibroblasts. Arthritis Rheum 2009:60:3455-64.

7 Bogatkevich GS, Ludwicka-Bradley A, Nietert PJ, et al. Antiinflammatory and antifibrotic effects of the oral direct thrombin inhibitor dabigatran etexilate in a murine model of interstitial lung disease. Arthritis Rheum 2011;63:1416-25.

Copyright 2018 BMJ Publishing Group. All rights reserved. For permission to reuse any of this content visit

http://group.bmj.com/group/rights-licensing/permissions.

BMJ Case Report Fellows may re-use this article for personal use and teaching without any further permission.

Become a Fellow of BMJ Case Reports today and you can:

- Submit as many cases as you like

- Enjoy fast sympathetic peer review and rapid publication of accepted articles

- Access all the published articles

- Re-use any of the published material for personal use and teaching without further permission

For information on Institutional Fellowships contact consortiasales@bmjgroup.com

Visit casereports.bmj.com for more articles like this and to become a Fellow 